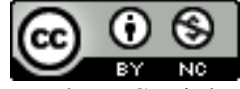

JurnalPendidikanIlmuPengetahuanSosial Indonesia is licensed under

A Creative Commons Attribution-Non Commercial 4.0 International License.

\title{
PEMBENTUKAN KARAKTER TOLERANSI MELALUI HABITUASI SEKOLAH
}

\author{
Yohana Yosiphanungkas Bahari Mandayu \\ ${ }^{1)}$ Universitas Tanjungpura, Pontianak, Indonesia \\ E-mail: yohanayossibahari@gmail.com
}

\begin{abstract}
Abstrak. Tujuan penelitian ini adalah untuk mengetahui pembentukan karakter toleransi melalui habituasi di sekolah. Pendekatan yang digunakan adalah pendekatan kualitatif dengan metode deskriptif. Teknik pengumpulan data yang digunakan adalah dokumentasi, observasi, dan wawancara. Tempat penelitian adalah SD Bruder Melati, Pontianak, Kalimantan Barat. Berdasarkan penelitian yang peneliti lakukan, habituasi sekolah di SD Bruder Melati dilakukan melalui pembauran tempat duduk siswa dan perayaan dua hari besar agama/etnis mayoritas di sekolah, yaitu Perayaan Natal dan Tahun Baru Imlek. Hal ini cukup unik mengingat SD Bruder Melati berlindung di Yayasan Pendidikan Katolik dengan mayoritas siswa beragama Budha. Adapun perayaan dua hari besar tersebut merupakan upaya pembiasaan sekolah dalam pembentukan karakter toleransi siswa di SD Bruder Melati sehingga siswa dihimbau menggunakan pakaian atau aksesoris St. Claus pada perayaan Natal dan Congsam (Cheongsam) pada perayaan Tahun Baru Imlek. Selain daripada itu, habituasi sekolah lainnya adalah melalui pembiasaan: (1) Mengenakan pakaian nasional (Kebaya) dalam peringatan Hari Pendidikan Nasional; (2) Mengenakan pakaian tradisional pada Hari Kartini, mewakili berbagai etnis di Kalimantan Barat; (3) Memfasilitasi siswa penyandang disabilitas sebagai bentuk toleransi dan keberpihakan sekolah terhadap kaum miskin, lemah, dan sakit. Habituasi sekolah tersebut merupakan upaya sekolah untuk menjaga iklim keberagaman dalam bingkai Bhinneka Tunggal Ika.
\end{abstract}

Kata Kunci: Pembentukan Karakter, Toleransi, Habituasi Sekolah

\section{PENDAHULUAN}

Pendidikan karakter merupakan usaha secara sadar dan berkesinambungan di dalam menghadapi tantangan pergeseran karakter bangsa dewasa ini. Adapun tujuan pendidikan karakter adalah untuk mengembangkan kemampuan seseorang di dalam menimbang dan memutuskan sesuatu yang baik atau buruk, memelihara serta mewujudkan kebaikan pada kehidupan sehari-hari dalam keadaan sadar dan dengan sepenuh hati. Di dalam pelaksanaannya, pendidikan karakter memerlukan suatu wadah atau dikenal dengan communities of character, yaitu lingkungan keluarga, sekolah, dan masyarakat. Sebagai jembatan penghubung yang menempati posisi kedua setelah keluarga, maka peranan sekolah menjadi sangat penting di dalam pembentukan karakter peserta didik itu sendiri.

Dewasa ini, dunia pendidikan dikejutkan dengan maraknya kasus bullying yang menimpa anak-anak di bawah umur, bahkan tidak luput menimpa anak-anak usia sekolah dasar di Indonesia. KPAI atau Komisi Perlindungan Anak Indonesia mencatat terdapat 161 kasus kekerasan anak di bidang Pendidikan selama 2018 (iNews.id pada Senin, 23 Juli 2018-15:03 WIB).

KPAI (iNews.id pada Senin, 23 Juli 2018-15:03 WIB) menerangkan bahwa kasus kekerasan anak di bidang pendidikan pada tahun 2018 menempati posisi ke empat teratas, setelah kasus pornografi dan cyber crime (kejahatan siber).

Adapun jumlah pengaduan kekerasan di sekolah yang dilaporkan masyarakat secara langsung ke KPAI (dalam iNews.id pada Senin, 23 Juli 2018-15:03 WIB) sampai dengan 17 Juli 2018 adalah berjumlah 27 kasus, dengan kasus kekerasan terbanyak berasal dari jenjang SD sebanyak 13 kasus (48\%), disusul dari jenjang SMA/SMK sebanyak 9 kasus $(34,7 \%)$, dan SMP sebanyak 5 kasus $(17,3 \%)$.

Kasus-kasus kekerasan tersebut sangatlah memprihatinkan dan menciderai dunia pendidikan. Apabila hal ini dibiarkan secara terus-menerus, maka berpotensi meningkatkan rasa intoleran generasi millenial yang kemudian dapat berpengaruh pada kemerosotan moral bangsa di masa mendatang. Sebagaimana yang dikemukakan oleh Lickona (1992 dalam Komalasari dan Saripudin, 2017:31-32), bahwa 1) meningkatnya kekerasan di kalangan remaja, 2) penggunaan bahasa dan kata-kata yang buruk, 3) semakin kaburnya pedoman moral baik dan buruk, 4) adanya rasa curiga dan kebencian di antara sesama; adalah empat dari sepuluh tanda penurunan kualitas karakter. Apabila tanda-tanda ini sudah ada, maka berpotensi membawa kehancuran pada sebuah bangsa. Oleh karena itu, penulis memandang perlu diadakan suatu upaya meniadakan kasus- 
kasus kekerasan tersebut, atau sekurang-kurangnya untuk meminimalisir kasus-kasus serupa.

SD Bruder Melati merupakan sekolah dasar swasta Katolik yang bernaung di dalam Yayasan Pendidikan Sekolah Bruder. Adapun, para siswa SD Bruder Melati berasal dari berbagai latar belakang yang berbeda, seperti: suku, agama, ras, dan golongan. Perbedaan latar-belakang tersebut pada dasarnya berpotensi menimbulkan konflik, seperti halnya kasus bullying yang marak terjadi di sekolah. Namun, pada kenyataannya, konflik semacam itu tidaklah terjadi di SD Bruder Melati.

Menurut Kepala Sekolah SD Bruder Melati, habituasi sekolah merupakan upaya pembentukan karakter toleransi yang sekolah lakukan dan memiliki dampak positif pada karakter toleransi siswa SD Bruder Melati yang berasal dari berbagai latar-belakang yang berbeda tersebut.

Bertolak dari latar-belakang di atas, maka penulis memandang diperlukanlah suatu kajian mengenai habituasi atau pembiasaan yang sekolah lakukan dalam kaitan dengan pembentukan karakter toleransi siswa. Penelitian ini dilakukan di SD Bruder Melati, Pontianak, yang notabene merupakan sekolah Katolik yang didominasi oleh siswa beragama Budha dari etnis Tionghoa.

\section{PENDIDIKAN KARAKTER TOLERANSI MELALUI HABITUASI SEKOLAH}

Elkind dan Sweet (Fitria, 2017:16) mendefinisikan pendidikan karakter sebagai upaya yang sengajadilakukan untuk membantu memahami manusia, peduli dan inti atas nilai-nilai etika dan asusila. Ketika kita berpikir tentang bermacam karakter yang kita inginkan bagi anak kita, ini jelas bahwa kita menginginkan mereka mampu menilai apa itu kebenaran, sangat peduli mengenai apa itu kebenaran/hak-hak, dan kemudian melakukan apa yang mereka percayai menjadi yang sebenarnya, bahkan dalam menghadapi tekanan dari tanpa dan dalam godaan.

Thomas Lickona dalam Fitria (2017:20) mengemukakan bahwa: Character education is the deliberate effort to help people understand, care about, and act upon core ethical values; yaitu pendidikan karakter adalah usaha sengaja untuk membantu manusia memahami, peduli, dan melaksanakan nilai-nilai inti etika.

Lickona (1992:51 dalam Komalasari dan Saripudin, 2017:11) menekankan pentingnya tiga komponen karakter yang baik, yaitu: karakter yang baik terdiri atas mengetahui kebaikan (knowing the good), mencintai atau menginginkan kebaikan (loving or desiring the good), dan melakukan kebaikan (acting the good).

Berdasarkan Lima Nilai Utama Karakter Bangsa menurut Gerakan Penguatan Pendidikan Karakter (PPK) yang dicanangkan Kementerian Pendidikan dan Kebudayaan (2017a dalam Komalasari dan Saripudin, 2017:9-11), yaitu Religius, Nasionalis, Mandiri, Gotong Royong, dan Integritas, maka toleransi menempati empat subnilai dari kelima nilai utama karakter bangsa tersebut, yaitu subnilai religius (toleransi), subnilai nasionalis (menghormati keragaman budaya, suku, dan agama), subnilai gotong royong (menghargai, kerjasama, komitmen atas keputusan bersama, tolong-menolong, solidaritas, empati, anti diskriminasi, anti kekerasan), dan subnilai integritas (menghargai martabat individu, terutama penyandang disabilitas).

Butir-butir refleksi toleransi menurut Tillman (2004:91 dalam Komalasari dan Saripudin, 2017:43), yaitu:

a. Kedamaian adalah tujuan, toleransi metodenya.

b. Toleransi adalah terbuka dan reseptif pada indahnya perbedaan.

c. Toleransi menghargai individu dan perbedaannya, menghapus topeng dan ketegangan yang disebabkan oleh ketidakpedulian.

d. Menyediakan kesempatan untuk menemukan dan menghapus stigma yang disebabkan oleh kebangsaan, agama, dan apa yang diwariskan.

Komalasari dan Saripudin (2017:43) memandang butirbutir toleransi Tillman tersebut sangat mendukung terciptanya kedamaian dalam kehidupan di masyarakat, mengingat setting sosial masyarakat Indonesia yang majemuk dengan aneka-ragam budaya, bahasa, agama dan kepercayaan. Nilai toleransi merupakan harga mati yang harus dipertahankan guna menciptakan kehidupan yang harmonis terbebas dari konflik berkepanjangan dan jatuhnya korban akibat sikap anti toleransi.

Berdasarkan pendapat para ahli di atas, maka penulis memandang toleransi merupakan satu dari berbagai karakter yang sejak dini perlu ditanamkan dan dibentuk pada peserta didik. Sikap ini berkaitan dengan kesadaran diri dan kecakapan sosial, seperti sikap saling menghargai, demokratis, bersahabat, cinta perdamaian dan persatuan, kepedulian sosial, empati dan kerjasama. Melalui toleransi, niscaya dapat mewujudkan kehidupan masyarakat Indonesia yang harmonis, bebas konflik, bebas sikap intoleran, dan memandang kemajemukan sebagai keindahan dalam bingkai Bhinneka Tunggal Ika.

Megawangi (2004:25 dalam Komalasari dan Saripudin, 2017:18-19) menyimpulkan berbagai pendapat para pakar pendidikan karakter bahwa terbentuknya karakter atau kepribadian manusia ditentukan oleh dua faktor, yaitu nature (faktor alami atau fitrah/ kecenderungan baik) dan nurture (sosialisasi dan pendidikan).

Hidayatullah (2010, dalam Haryati, 2017:13) menyatakan bahwa strategi dalam pendidikan karakter dapat dilakukan melalui sikap-sikap berikut, yakni: keteladanan, penanaman kedisiplinan, pembiasaan, menciptakansuasana yang kondusif, serta integrasi dan internalisasi.

Berdasarkan pendapat para ahli di atas, maka penulis memandang bahwa habituasi atau pembiasaan sekolah merupakan salah satu upaya sekolah dalam pembentukan karak tertoleransi di sekolah dalam kaitan dengan peranan sekolah sebagai wadah pembentukan karakter (communities of character), sekaligus strategi dalam dunia pendidikan yang sekolah lakukan melalui habituasi sebagai faktor eksternal dalam pembentukan karakter toleransi tersebut (nurture).

\section{KESIMPULAN}


Habituasi atau pembiasaan sekolah dalam pembentukan karakter toleransi siswa di SD Bruder Melati Pontianak, adalah melalui:

a. Pembauran tempat duduk siswa.

b. Merayakan Hari Raya Natal dan Tahun Baru Imlek di sekolah.

c. Mengenakan pakaian atau aksesoris bertema St. Claus padaPerayaan Natal.

d. Mengenakan Congsam/Cheongsam (pakaian tradisional Tionghoa/China) pada Perayaan Imlek di sekolah.

e. Mengenakan pakaian nasional (Kebaya) dalam Peringatan Hari Pendidikan Nasional.

f. Mengenakan pakaian tradisional/adat (dapat mewakili etnis Melayu, Dayak, Tionghoa, Jawa, dll) pada Peringatan Hari Kartini.

g. Memfasilitasi siswa penyandang disabilitas, sebagai bentuk toleransi dan keberpihakan sekolah terhadap kaum miskin, lemah, dan sakit.

Adapun penulis merekomendasi Dinas Pendidikan dan Kebudayaan Kota Pontianak untuk menjadikan SD Bruder Melati sebagai sekolah percontohan dalam pembentukan karakter toleransi pada siswa heterogen, di Indonesia secara umum, di Kalimantan Barat secarakhusus, guna meminimalisir marak sikap intoleran di Negara Kesatuan Republik Indonesia.

\section{REFERENCES}

Agbola, Alex and Kaun Chen Tsai. (2012). Bring character education into classroom. european journal of education research, Volume 1, Number 2, p.163170. San Antonio, USA: University of the Incarnate Word.

AlkitabDeuterokanonika. (2018). Jakarta: LembagaAlkitab Indonesia.

Brese, Falk. (2015). Tolerance towards minority groups amongst european students. Book of tolerance through education, p.19-33. Germany: IEA Data Processing and Research Center.

Fitria, Nurul. (2017). Konsep pendidikan karakter menurut thomas lickona dan yusuf qardhawi (Studi komparatif tentang metode, strategi dan konten). Tesis. Yogyakarta: Universitas Islam Negeri Sunan Kalijaga.

Haryati, Sri. (2017). Pendidikan Karakter dalam Kurikulum 2013: lib.untidar.ac.id>2017/01PDF diakses tanggal 15 Juli 2019.

Islamov, Artem E et.al. (2017). Students' tolerant behavior formation mechanisms. International Electronic of Mathematics Education e-ISSN: 1360-3030, Volume 12, Number 1, p.43-50

Khoury, Ruba. (2017). Character education as a bridge from elementary to middle school: A Case Study of Effective Practices and Processes. International Journal of Teacher Leadership Volume 8, Number 3, Fall 2017. Pamona, USA: California State Polytechnic University.
Komalasari, Kokom dan Didin Saripudin. (2017). Pendidikan karakter konsep dan aplikasi living values education. Bandung: PT Refika Aditama.

Lickona, Thomas.

(2016).

Mendidikuntukmembentukkarakter:

Bagaimanasekolahdapatmemberikanpendidikantent angsikaphormatdanbertanggungjawab.

(Penterjemah: Juma Abdu Wamaungo). Jakarta: BumiAksara

Magdalena, Maria Isac (Editor) et.al.(2015). Tolerance through education: Mapping the determinants of young people's attitudes towards equal rights for immigrants and ethnic/racial minoroties in europe. Luxembourg: European Union.

Magdalena, Maria Isac et. al. (2018). Teaching tolerance in a globalized world: Final remarks. International Association for the Evaluation of Educational Achievement (IEA) Research for Education 4, [https://doi.org/10.1007/978-3-319-786926_8],p.125-135.

Nuraini, Asriati dkk. (2017). Pedoman penulisan karya ilmiah skripsi, tesis, dan artikel hasil penelitian. Pontianak: Universitas Tanjungpura.

Pala, Aynur. (2011). The need for character education. International Journal of Social Sciences and Humanity Studies, Volume 3, Number 2, 2011. Turkey: Celal Bayar University.

Peraturan Pemerintah Republik Indonesia Nomor 55 Tahun 2007 Tentang Pendidikan Agama dan Pendidikan Keagamaan. Lembaran Negara Republik Indonesia Tahun 2007 Nomor 124. Jakarta: Kementerian Hukum dan Hak Asasi Manusia Republik Indonesia.

Saefuddin, AzisdanIkaBerdiati.(2016). Pembelajaranefektif. Bandung: RemajaRosdakarya.

Sugiyono. (2018). Metode penelitian pendidikan (Pendekatan kuantitatif, kualitatif dan r\&d). Bandung: CV Alfabeta.

Yosiphanungkas, YohanaBahariMandayu. (2015). The effect of group investigation technique for english speaking practice. Skripsi. Pontianak: UniversitasTanjungpura.

Zubaidah, Siti. (2015). Implementasi pendidikan karakter dalam pendidikan agama islam di sd gayamsari 02 semarang. Skripsi. Semarang: Universitas Islam Negeri Walisongo.

https://komkat-kwi.org/2014/02/21/implementasi-kurikulum 2013/ diakses 1 Juli 2019.

https://www.google.com/amp/s/www.inews.id/news/amp/kp ai-catat-161-kasus-kekerasan-anak-di-bidangpendidikan-selama-2018/189701diakses 24 Juni 2019.

http://www.kpai.go.id/berita/kpai-kasus-bullying-danpendidikan-karakter diakses 24 Juni 2019.

https://text-id.123dok.com/document/nzw30k87y-tujuanpendidikan-agama-katolik.html diakses 1 Juli 2019. 